\title{
Formulasi Crispy Cookies Berbahan Baku Tepung Kacang Koro Pedang (Canavalia ensiformis) Termodifikasi
}

\section{Crispy Cookies Formulation from Modified Jack Bean (Canavalia ensiformis) Flour}

\section{Sri Rejeki Retna Pertiwi ${ }^{1, a}$, Intan Kusumaningrum${ }^{1}$, Uswatun Khasanah ${ }^{1}$}

1Jurusan Teknologi Pangan dan Gizi, Fakultas Ilmu Pangan Halal, Universitas Djuanda Bogor; Jl. Tol Ciawi No.1, Kotak Pos 35 Ciawi, Bogor 16720.

aKorespondensi: Sri Rejeki Retna Pertiwi,E-mail: sri.rejeki.pertiwi@unida.ac.id

(Diterima oleh Dewan Redaksi : 6 - 03 - 2018)

(Dipublikasikan oleh Dewan Redaksi : 14 - 04 - 2018)

\begin{abstract}
This research was conducted to obtain the influence between the comparison of modified jack bean flour with cornstarch $(100: 0,90: 10,80: 10,70: 30,60: 40$, and 50:50) in crispy cookies formulation to obtain the selected formulation sensory values of the product which examined by professional panelists and to analyze the nutritional values of the product. This research was divided into two stages : preparation and main research. Preparation stage consists of making modified jack bean flour. Main research stage consists of (1) Producing crispy cookies, (2) Organoleptic testing by Qualitative Descriptive Analysis method, (3) Physical testing (crispness), (4) Data analysis and (5) Chemical analysis for the selected formula. The results showed that the cookies produced from jack bean flour still have undesirable sensoric characters such as unpleasant aroma; bitter and sour taste; bitter, sour, and beany after taste. The selected formula was the formula with the comparison of modified jack bean flour : cornstarch $=60: 40$. The chemical analysis results of the selected formula were: water content of $1.34 \%$, ash content of $2.14 \%$, protein value of $14.33 \%$, fat of $30.30 \%$,fibre of $0.30 \%$, carbohydrate of $51.89 \%$, and $\mathrm{HCN}$ of $0.01 \%$.
\end{abstract}

Keywords: jack bean, modified flour, cornstarch, cookies

\begin{abstract}
ABSTRAK
Penelitian ini dilakukan untuk mengetahui pengaruh perbandingan pemakaian tepung kacang koro pedang termodifikasi dengan tepung maizena (100:0, 90:10, 80:10, 70:30, 60:40, dan 50:50) dalam pembuatan crispy cookies untuk memperoleh formulasi terpilih berdasarkan uji sensori produk oleh panelis terlatih dan menganalisis kandungan gizi dari produk. Penelitian ini dibagi menjadi dua tahap yaitu tahap preparasi dan penelitian utama. Tahap preparasi adalah tahap pembuatan tepung kacang koro pedang termodifikasi. Tahap penelitian utama terdiri dari (1) Pembuatan crispy cookies, (2) Uji organoleptik metode Analisis Deskriptif Kualitatif, (3) Uji Fisik (kerenyahan), (4) Analisis data dan (5) Analisis kimia formula terpilih. Cookies yang dihasilkan dari bahan baku tepung kacang koro pedang termodifikasi masih memiliki karakteristik sensori yang tidak diinginkan oleh panelis seperti aroma langu, rasa pahit, rasa asam, after taste asam, after taste pahit, dan after taste langu. Formulasi terpilih adalah formula dengan perbandingan tepung kacang koro pedang termodifikasi : tepung maizena $=60: 40$. Analisis kimia formula terpilih yaitu kadar air 1,34\%, kadar abu 2,14\%, kadar protein $14,33 \%$, kadar lemak total 30,30\%, kadar serat kasar 0,30\%, karbohidrat 51,89\% dan HCN $0,01 \%$.
\end{abstract}

Kata Kunci: kacang koro pedang, tepung modifikasi, maizena, cookies

Pertiwi, Sri Rejeki Retna, Intan Kusumaningrum, Uswatun Khasanah. 2018. Formulasi Crispy Cookies Berbahan Baku Tepung Kacang Koro Pedang (Canavalia ensiformis) Termodifikasi.Jurnal Agroindustri Halal 4(1): 068 - 078. 


\section{PENDAHULUAN}

Kacang koro pedang (Canavalia ensiformis) merupakan salah satu tanaman lokal yang dapat ditemukan dengan mudah di Indonesia. Kacang koro pedang kini telah tersebar di seluruh daerah tropis dan telah dibudidaya di beberapa daerah, termasuk wilayah Jawa Tengah. Salah satu daerah penghasil kacang koro pedang adalah Kabupaten Temanggung Jawa Tengah. Para petani kacang koro pedang yang terhimpun dalam Komunitas Damar Sindoro Sumbing di Temanggung Jawa Tengah mampu menghasilkan 4-8 ton koro pedang setiap panen (Kasno dkk., 2016).

Kacang koro pedang mengandung protein 18-25\%, lemak $0,2-3,0 \%$ dan karbohidrat 50-60\% (Van Der Mesen dan Somaatmaja, 1993). Selain memiliki nilai gizi yang cukup tinggi kacang koro pedang mempunyai kelemahan yaitu mengandung senyawa HCN yang bersifat toksik bagi tubuh. Standar SNI 01-2997-1996 mensyaratkan kadar HCN maksimal pada tepung adalah 0,04\%. HCN ini dapat dikurangi atau dihilangkan dengan beberapa perlakuan antara lain dengan perendaman, pengukusan dan perebusan dengan menggunakan suhu relatif tinggi (Wardiyono, 2008).

Komposisi gizi kacang koro pedang yang cukup tinggi merupakan salah satu peluang baru untuk dimanfaatkan sebagai bahan baku produk protein richflour (PRF) atau tepung kaya protein. Salah satu pemanfaatan tepung kacang kacang koro pedang adalah sebagai bahan baku pembuatan cookies. Tepung kacang koro pedang merupakan salah satu jenis tepung yang tidak memiliki protein gluten seperti pada tepung terigu, berpotensi dalam mensubtitusi tepung terigu pada cookies yang tidak membutuhkan pengembangan terlalu besar dan dapat digunakan sebagai salah satu sumber pangan bagi orang yang intoleransi terhadap protein gluten atau celiac.

Cookies merupakan salah satu produk pangan yang banyak digemari oleh masyarakat dari berbagai kalangan, konsumsi rata-rata kue kering di Indonesia adalah 0,1 Kg per kapita per tahun (EPublikasi, 2015). Tepung terigu yang digunakan dalam pembuatan cookies pada umumnya merupakan tepung terigu protein rendah dan merupakan tepung terigu dengan kadar gluten yang rendah. Oleh karena itu, tepung kacang koro pedang termodifikasi ini diharapkan dapat menjadi alternatif bahan baku selain tepung terigu.

Hasil dari penelitian ini yaitu diharapkan cookies yang dibuat memiliki karakteristik yang khas yaitu renyah (crispy) dan memiliki karakteristik lain yang baik seperti cookies pada umumnya. Untuk menghasilkan cookies dengan karakteristik tersebut maka dalam penelitian ini digunakan tepung maizena sebagai bahan tambahan. Tepung maizena mempunyai kandungan amilopektin yang lebih tinggi dibandingan dengan tepung kacang koro pedang termodifikasi yang akan memberikan tekstur yang lebih kokoh pada cookies dan memberikan tekstur yang renyah (Utomo dkk., 2015).

\section{MATERI DAN METODE}

\section{Bahan dan Alat}

Bahan-bahan yang digunakan dalam penelitian yaitu kacang koro pedang, asam laktat $1,5 \%$, tepung maizena, gula, putih telur, kuning telur, susu bubuk, margarin, air suling, larutan kalium sulfat $\left(\mathrm{K}_{2} \mathrm{SO}_{4}\right)$, air raksa oksida ( $\mathrm{HgO})$, asam borat jenuh $\left(\mathrm{H}_{2} \mathrm{BO}_{3}\right)$, larutan natrium hidroksida $(\mathrm{NaOH})$ pekat, larutan asam klorida ( $\mathrm{HCl})$, heksana, kertas saring, asam sulfat $\left(\mathrm{H}_{2} \mathrm{SO}_{4}\right)$, aseton, dan asam pikrat.

Alat yang digunakan yaitu baskom, blender kering (untuk penepungan), ayakan 80 mesh, pengaduk, water bath, termometer, oven, cabinet dryer, loyang alumunium, baking paper, mixer, cetakan, kompor gas, sendok, timbangan digital, panci, neraca analitik, oven, desikator, botol timbang, cawan porselen, labu ukur, piala gelas, labu lemak, labu semprot, erlenmeyer, buret, tanur, kondensor, pipet 
tetes, pipet volume, dan texsture analyzer tipe TA-XT2i dengan probe 0,25S.

\section{Tahap Preparasi}

Tahap preparasi meliputi tahap pengadaan tepung kacang koro pedang termodifikasi. Prosedur pembuatan tepung kacang koro pedang termodifikasi dapat dilihat pada Gambar 1.
A5 (K 50 : M 50), uji organoleptik metode QDA (Qualitatif Deskriptif Analysis), uji fisik (kerenyahan) dan analisis data. Formulasi bahan yang digunakan dalam pembuatan crispy cookies ini dapat dilihat pada Tabel 1. Prosedur pengolahan crispy cookies dilihat pada Gambar 2.

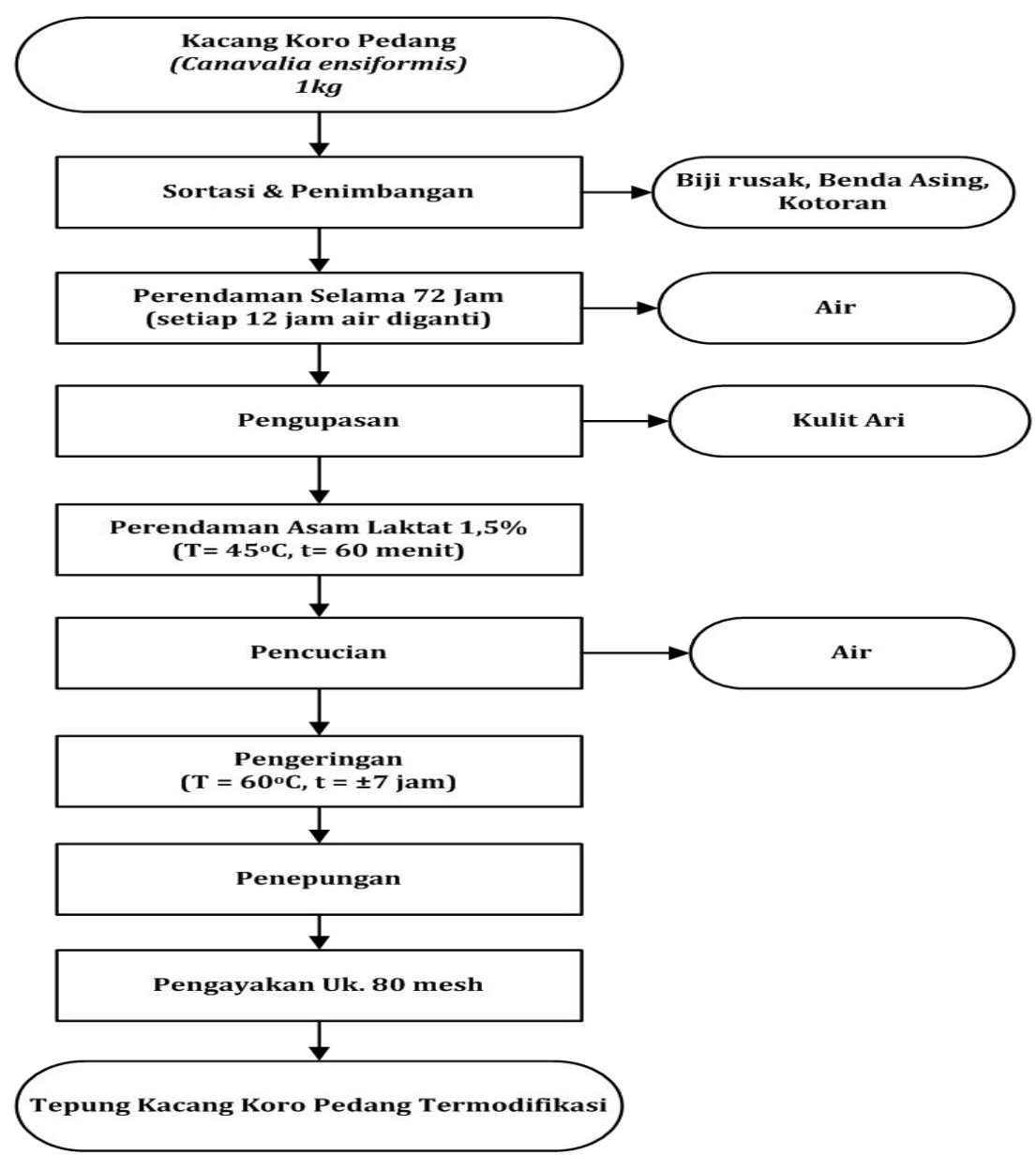

Gambar 1. Diagram alir proses pembuatan tepung kacang koro pedang (Canavalia ensiformis) termodifikasi (Ariyantoro dkk., 2016)

\section{Tahap Penelitian Utama}

Penelitian utama terdiri dari formulasi crispy cookies dengan 6(enam) variasi perbandingan penggunaan tepung kacang koro pedang $(\mathrm{K})$ : tepung maizena $(\mathrm{M})$, yaitu: A0 (K 100 : M 0), A1 (K 90 : M 10), A2 (K 80 : M 20), A3 (K $70:$ M 30), A4 ( K $60:$ M 40), 


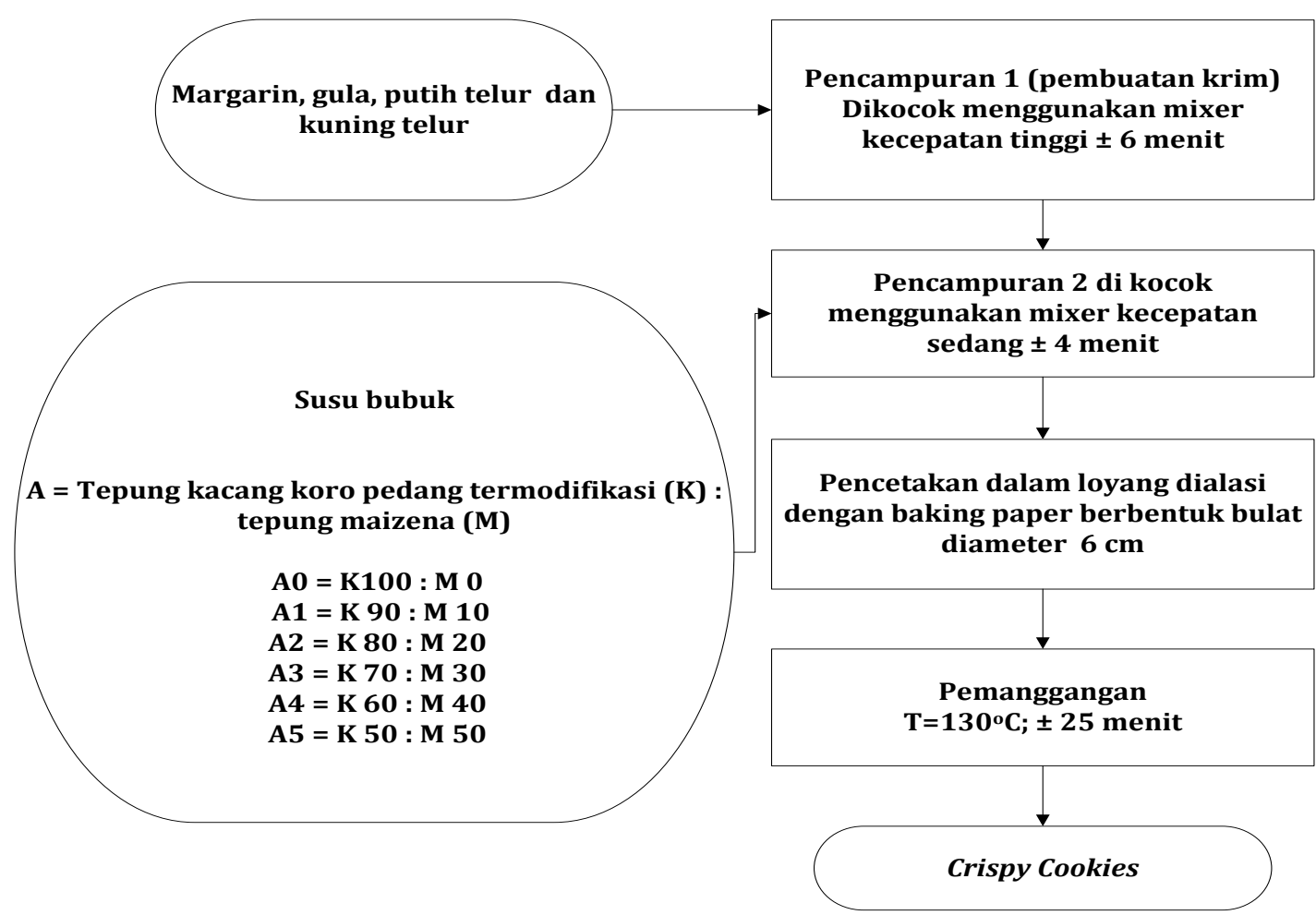

Gambar 2. Diagram alir proses pembuatan crispy cookies (Suarni (2005) dengan modifikasi dari Chusna (2017)

Tabel 1. Formula pembuatan crispy cookies berbahan baku tepung kacang koro pedang termodifikasi dan produk reference (dalam persen).

\begin{tabular}{|c|c|c|c|c|c|c|c|}
\hline Nama Bahan & Reference & $\mathrm{A} 0$ & $\mathrm{~A} 1$ & A2 & A3 & $\mathrm{A} 4$ & A5 \\
\hline $\begin{array}{l}\text { Tepung kacang koro } \\
\text { pedang termodifikasi }\end{array}$ & - & 100 & 90 & 80 & 70 & 60 & 50 \\
\hline $\begin{array}{l}\text { Tepung terigu protein } \\
\text { rendah }\end{array}$ & 100 & - & - & - & - & - & - \\
\hline Tepung maizena*) & - & - & 10 & 20 & 30 & 40 & 50 \\
\hline Putih telur*) & 80 & 80 & 80 & 80 & 80 & 80 & 80 \\
\hline Kuning telur*) & 20 & 20 & 20 & 20 & 20 & 20 & 20 \\
\hline Margarin*) & 100 & 100 & 100 & 100 & 100 & 100 & 100 \\
\hline Gula*) & 80 & 80 & 80 & 80 & 80 & 80 & 80 \\
\hline Susu bubuk*) & 30 & 30 & 30 & 30 & 30 & 30 & 30 \\
\hline
\end{tabular}

Keterangan : ${ }^{*}$ ) basis 100\% tepung

\section{Analisis Produk}

Uji organoleptik dilakukan dengan metode QDA oleh 6 panelis terlatih menggunakan skala garis 0-15 (tidak terdeteksi hingga sangat terdeteksi) dengan menggunakan produk reference sebagai pembanding. Atribut sensori yang dijadikan sebagai acuan parameter uji diperoleh dari hasil Focus Group Discussion panelis.

Uji fisik dilakukan dengan menggunakan alat texture analyzer tipe TA-XT2i dengan probe $0,25 S$. 
Formula terpilih hasil uji QDA dianalisis kimia yaitu kadar air, kadar abu, kadar protein, kadar serat kasar, kadar lemak, karbohidrat, dan HCN.

\section{Analisis Data}

Data hasil uji organoleptik dan uji fisik diolah dengan analisis sidik ragam (ANOVA) dan uji lanjut DUNCAN dengan menggunakan SPSS 17.0.

\section{HASIL DAN PEMBAHASAN}

\section{Penelitian Tahap Preparasi}

Pada tahap ini dilakukan preparasi tepung kacang koro pedang termodifikasi yang akan digunakan dalam pembuatan crispy cookies. Pembuatan tepung kacang koro pedang termodifikasi mengikuti prosedur hasil penelitian terbaik yang dilakukan oleh Ariyantoro dkk. (2016). Tepung kacang koro pedang termasuk tepung yang kaya protein atau protein rich flour (PRF) karena kandungan proteinnya yang cukup tinggi yaitu sekitar 37\% (Widyawati, 2010). Tepung kacang koro pedang yang dibuat dengan cara konvensional menghasilkan tepung yang memiliki karakteristik kurang baik sehingga dilakukan modifikasi dengan perlakuan perendaman dalam asam laktat. Hasil penelitian menyatakan bahwa semakin besar konsentrasi asam laktat dan semakin lama waktu perendaman cenderung meningkatkan kandungan amilosa, daya serap air, kelarutan, swelling power, dan derajat putih tepung kacang koro pedang termodifikasi, namun menurunkan kadar air dan kadar protein tepung kacang koro pedang termodifikasi (Ariyantoro dkk,. 2016).

\section{Penelitian Tahap Pembuatan Crispy Cookies}

Pembuatan crispy cookies menggunakan faktor enam variasi perbandingan penggunaan tepung kacang koro pedang termodifikasi dengan tepung maizena $(100 \mathrm{~g}$ :0g, 90g :10g, 80g : 20g, 70g :30g, 60g : 40g, dan 50g : 50g) dengan ulangan sebanyak dua kali. Proses pembuatan adonan cookies terbagi menjadi dua tahap yaitu proses pembentukan krim kemudian dilanjukan dengan pencampuran bahan kering. Adonan yang telah siap dicetak kemudian dioven pada suhu $130^{\circ} \mathrm{C}$ selama \pm 25 menit. Cookies yang telah matang didinginkan segera dan langsung dimasukan ke dalam wadah tertutup agar teksturnya tetap renyah.

\section{Uji Qualitatif Deskriptif Analysis}

Uji deskripsi digunakan untuk mengidentifikasi karakteristik sensori yang penting pada suatu produk pangan sehingga dapat memberikan informasi tingkatan atau intensitas dan karakteristik produk. Informasi deskripsi dapat membantu dalam mengidentifikasi komposisi atau variabel proses yang menyusun karakteristik sensori produk crispy cookies kacang koro pedang. Uji QDA ini digunakan untuk menentukan formulasi terpilih dari hasil respon panelis terhadap aroma (langu, milky, buttery), rasa (pahit, asam, manis, milky, asin), tekstur (kerenyahan), after taste (asam, pahit, langu), dan kenampakan (keseragaman diameter, tingkat kematangan, ketebalan, warna kekuningan-coklat, keseragaman warna). Skala penilaian yang digunakan pada QDA adalah skala garis tidak terstruktur 0-15 respon tidak terdeteksi hingga sangat terdeteksi pada masingmasing parameter. Pengujian QDA dilakukan oleh 6 orang panelis terlatih sebanyak dua kali ulangan. Nilai rata-rata uji organoleptik terhadap aroma, rasa, tekstur, after taste, dan kenampakan crispy cookies dapat dilihat pada Tabel 2. 
Tabel 2. Nilai rata-rata hasil uji organoleptik crispy cookies berbahan baku tepung kacang koro pedang termodifikasi

\begin{tabular}{|c|c|c|c|c|c|c|c|}
\hline $\begin{array}{l}\text { Atribut } \\
\text { Sensori }\end{array}$ & Atribut Mutu & A0 & A1 & A2 & A3 & A4 & A5 \\
\hline \multirow[t]{3}{*}{ Aroma } & Langu & $11,88^{c}$ & $9,44^{b}$ & $9,63^{b}$ & $9,52^{b}$ & $8,10^{a, b}$ & $6,63^{a}$ \\
\hline & Milky & $7,86^{\mathrm{a}}$ & $8,73^{a, b}$ & $9,23^{a, b}$ & $9,12^{a, b}$ & $10,22^{b, c}$ & $11,23^{c}$ \\
\hline & Buttery & $8,69^{a}$ & $9,74^{a, b, c}$ & $8,90^{a, b}$ & $10,15^{a, b, c}$ & $10,53^{b, c}$ & $11,36^{c}$ \\
\hline \multirow[t]{5}{*}{ Rasa } & Pahit & $9,917 \mathrm{c}$ & $8,99 \mathrm{~b}, \mathrm{c}$ & $8,02^{b, c}$ & $7,53^{b}$ & $5,53^{a}$ & $4,38^{a}$ \\
\hline & Manis & $7,41^{\mathrm{a}}$ & $8,22^{\mathrm{a}, \mathrm{b}}$ & $9,18^{b, c}$ & $8,55^{\mathrm{a}, \mathrm{b}, \mathrm{c}}$ & $9,84^{c}$ & $9,32^{b, c}$ \\
\hline & Asam & $9,36^{\mathrm{a}}$ & $8,63^{\mathrm{a}}$ & $7,87^{a}$ & $8,25^{\mathrm{a}}$ & $7,09^{a}$ & $6,89^{a}$ \\
\hline & Milky & $8,06^{a}$ & $8,92^{a}$ & $9,49^{a, b}$ & $8,93^{a}$ & $10,77^{b}$ & $10,47^{b}$ \\
\hline & Asin & $7,50^{a}$ & $6,02^{a}$ & $6,62^{\mathrm{a}}$ & $7,55^{a}$ & $7,56^{a}$ & $7,04^{a}$ \\
\hline Tekstur & Kerenyahan & $10,63^{\mathrm{a}}$ & $10,53^{a}$ & $10,90^{\mathrm{a}}$ & $11,28^{\mathrm{a}}$ & $12,59^{a}$ & $12,06^{\mathrm{a}}$ \\
\hline \multirow{3}{*}{$\begin{array}{l}\text { After } \\
\text { taste }\end{array}$} & Asam & $10,41^{\mathrm{c}}$ & $9,63^{b, c}$ & $9,01^{b, c}$ & $7,75^{\mathrm{a}, \mathrm{b}}$ & $8,30^{a, b, c}$ & $6,60^{\mathrm{a}}$ \\
\hline & Pahit & $8,96^{\mathrm{a}}$ & $6,93^{\mathrm{a}}$ & $11,11^{\mathrm{a}}$ & $6,60^{\mathrm{a}}$ & $5,95^{a}$ & $4,30^{\mathrm{a}}$ \\
\hline & Langu & $10,51^{a, b}$ & $9,38^{a, b}$ & $13,60^{\mathrm{b}}$ & $7,28^{a}$ & $6,74^{a}$ & $4,75^{\mathrm{a}, \mathrm{b}}$ \\
\hline \multirow{5}{*}{ 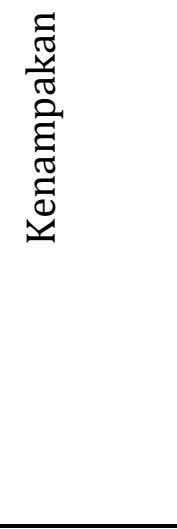 } & $\begin{array}{l}\text { Keseragaman } \\
\text { Diameter }\end{array}$ & $9,45^{a}$ & $10,78^{a}$ & $10,78^{a}$ & $10,12^{\mathrm{a}}$ & $11,23^{a}$ & $10,23^{\mathrm{a}}$ \\
\hline & $\begin{array}{l}\text { Tingkat } \\
\text { Kematangan }\end{array}$ & $8,26^{a}$ & $8,62^{\mathrm{a}}$ & $9,58^{a}$ & $9,66^{\mathrm{a}}$ & $8,88^{a}$ & $8,37^{a}$ \\
\hline & Ketebalan & $6,50^{\mathrm{a}}$ & $7,23^{a}$ & $8,17^{a}$ & $7,08 a$ & $7,90^{\mathrm{a}}$ & $6,75^{a}$ \\
\hline & $\begin{array}{l}\text { Warna } \\
\text { (Kekuningan- } \\
\text { Coklat) }\end{array}$ & $5,75^{a}$ & $6,92^{\mathrm{a}}$ & $6,66^{\mathrm{a}}$ & $8,76^{a}$ & $6,97^{a}$ & $6,58^{a}$ \\
\hline & $\begin{array}{l}\text { Keseragaman } \\
\text { Warna }\end{array}$ & $9,98^{a}$ & $9,68^{a}$ & $9,84^{\mathrm{a}}$ & $9,15^{\mathrm{a}}$ & $10,75^{a}$ & $10,68^{a}$ \\
\hline
\end{tabular}

\section{Keterangan :}

- $\quad \mathrm{A} 0=$ Tepung kacang koro pedang 100\%: Tepung Maizena 0\%

- $\quad \mathrm{A} 1=$ Tepung kacang koro pedang 90\% : Tepung Maizena $10 \%$

- $\quad \mathrm{A} 2=$ Tepung kacang koro pedang 80\% $\quad:$ Tepung Maizena 20\%

- $\quad \mathrm{A} 3=$ Tepung kacang koro pedang 70\% $\quad:$ Tepung Maizena 30\%

- $\quad A 4=$ Tepung kacang koro pedang 60\% : Tepung Maizena 40\%

- $\quad$ A5 = Tepung kacang koro pedang 50\% : Tepung Maizena 50\%

- $\quad$ Notasi huruf yang berbeda pada tabel menunjukkan berbeda nyata pada tingkat kepercayaan 95\% $(\alpha=0.05)$ pada uji DUNCAN 


\section{Aroma}

Aroma yang terdapat pada produk crispy cookies antara lain aroma langu, milky, dan buttery. Respon aroma langu pada crispy cookies semakin menurun dengan penambahan tepung maizena dibandingkan dengan crispy cookies berbahan baku 100\% tepung kacang koro pedang termodifikasi (Tabel 2). Aromalangu yang ditimbulkan merupakan aroma yang berasal dari tepung kacang koro pedang termodifikasi. Hal ini disebabkan dalam proses pengolahan, bau langu yang sulit untuk dihilangkan, ditimbulkan oleh enzim lipoksigenase yang bereaksi dengan lemak kacang (hidrolisis lemak oleh enzim lipokgenase), hasil reaksinya membentuk delapan senyawa volatil (mudah menguap) salah satunya yang paling memberikan rasa langu adalah etil fenil keton (Masitoh, 2006).

Respon terhadap aroma milky pada crispy cookies dengan penambahan tepung maizena mengalami peningkatan dibandingkan dengan crispy cookies berbahan baku 100\% tepung kacang koro pedang termodifikasi (Tabel 2).Aroma milky merupakan yang ditimbulkan karena adanya penambahan susu bubuk. Aroma milky dapat menjadi aroma khas pada suatu produk makanan. Menurut Buckle dkk., (1985), susu skim mengandung laktosa yang berfungsi membantu dalam pembentukan aroma.

Respon terhadap aroma buttery padacrispy cookiesdengan penambahan tepung maizena mengalami peningkatan dibandingkan dengan crispy cookies berbahan baku $100 \%$ tepung kacang koro pedang termodifikasi (Tabel 2). Aromabuttery ditimbulkan dari penggunaan margarin. Penggunaan margarin bertujuan untuk meningkatkan penerimaan, terutama flavor.Aroma yang keluar dari cookies diduga disebabkan adanya reaksi lemak yang ada pada formulasi cookies saat pemanggangan.Gula dan lemak mengalami gelatinisasi, gas $\mathrm{CO}_{2}$ dan komponen aroma dibebaskan (Sugiyono, 2011).

\section{Rasa}

Rasa yang terdapat pada crispy cookies adalah rasa pahit, manis, asam, milky dan asin. Perlakuan pemakaian tepung kacang koro pedang dan tepung maizena berpengaruh terhadap rasa pahit, manis, dam milkydan tidak berpengaruh terhadap rasa asam dan asin pada produk crispy cookies.

Respon terhadap rasa pahit pada cookies dengan penambahan tepung maizena mengalami penurunan dibandingkan dengan crispy cookies berbahan baku 100\% tepung kacang koro pedang termodifikasi (Tabel 2). Menurut Soliha (2008), cookies koro memiliki rasa yang khas koro yaitu sedikit pahit dan getir, hal tersebut dikarenakan masih adanya asam sianida yang terkandung meskipun dalam konsentrasi yang kecil.

Respon terhadap rasa manis pada crispy cookies dengan penambahan tepung maizena mengalami peningkatan dibandingkan dengan crispy cookies berbahan baku 100\% tepung kacang koro pedang termodifikasi (Tabel 2). Menurut Smith (1972), fungsi gula dalam proses pembuatan cookies adalah sebagai pemberi rasa manis dan untuk memperbaiki tekstur dan memberikan warna pada permukaan cookies.

Respon terhadap rasa milky pada crispy cookies mengalami peningkatan dibandingkan dengan crispy cookies berbahan baku $100 \%$ tepung kacang koro pedang termodifikasi (Tabel 2). Rasa milky ditimbulkan dari penggunaan susu pada bahan baku pembuatan crispy cookies.

Respon terhadap rasa asin pada crispy cookies menunjukan rata-rata yang sama pada semua perlakuan dalam pembuatan crispy cookies berbahan baku tepung kacang koro pedang dan tepung maizena (Tabel 2). Rasa asin yang ditimbulkan pada crispy cookies ddiduga itimbulkan dari margarin yang digunakan. Menurut Pamina Adolina (2007), syarat umum suatu margarin antara lain mengandung tidak kurag 80\% lemak, bahan pengelmusi, garam, bahan pengawet, pewarna, pewangi (dalam batas aman), serta vitamin. 


\section{Tekstur}

Respon terhadap tekstur pada crispy cookies menunjukan rata-rata yang sama pada semua perlakuan dalam pembuatan crispy cookies berbahan baku tepung kacang koro pedang dan tepung maizena (Tabel 2). Tekstur crispy cookies berbahan baku tepung kacang koro pedang dipengaruhi oleh bahan baku lain salah satunya adalah lemak yang digunakan. Menurut Winarno (1991), penambahan lemak dapat mempengaruhi sifat keplastisan dari adonan kue. Di dalam adonan, lemak memberikan fungsi shortening dan fungsi tekstur tsehingga cookies menjadi lebih renyah.

\section{After taste}

After taste merupakan adalah rasa yang masih tertinggal dimulut walaupun sampel sudah tidak di mulut lagi (Kartika, 1987). After taste yang terdeteksi pada crispy cookies adalah after taste asam, pahit dan langu. Respon terhadap after taste asam pada crispy cookies semakin menurun dengan penambahan tepung maizena dibandingkan dengan crispy cookies berbahan baku 100\% tepung kacang koro pedang termodifikasi (Tabel 2). Pada proses pembuatan kacang koro pedang dilakukan proses perendaman selama 72 jam, sehingga diduga bahwa pada proses pembentukan rasa asam pada tepung kacang koro pedang. Menurut Ali (2008), selama proses perendaman kedelai memberikan kesempatan pertumbuhan bakteri-bakteri asam laktat sehingga terjadi penurunan $\mathrm{pH}$ dalam biji menjadi sekitar4,5-5,3. Kondisi ini memungkinkan terhambatnya pertumbuhan bakteri pembusuk yang tidak tahan terhadap asam. Selain itu, peningkatan kualitas organoleptikmya juga terjadi dengan terbentuknya aroma dan rasa yang unik (asam).

Respon terhadap after taste menunjukan rata-rata terhadap respon panelis terhadap crispy cookies (Tabel 2). After taste pahit diduga ditimbulkan dari tepung kacang koro pedang termodifikasi yang merupakan salah satu tepung dengan kadar potein yang tinggi.
Asam-asam amino yang menimbulkan rasa pahit seperti lisin, arginin, prolin, fenilalanin, dan valin. Asam amino lisin merupakan asam amino yang memiliki rasa paling pahit dibandingkan asam amino penyebab rasa pahit lainnya (Kurniawati, 2012).

\section{Uji Fisik (Kerenyahan)}

Tekstur merupakan atribut mutu cookies yang cukup penting. Tekstur biasanya digunakan untuk menilai kualitas suatu cookies. Tekstur pada cookies meliputi kekerasan, kemudahan untuk dipatahkan, dan konsistensi pada gigitan pertama. Uji fisik yang dilakukan menggunakan texture analyser tipe TA-XT2i dengan probe $0,25 \mathrm{~s}$.

Prinsip pengukuran kekerasan dengan instrumen texture analyzer ialah mengukur besarnya gaya yang dibutuhkan untuk menekan sampel pada jarak yang telah ditentukan (Rosenthal, 1999).

Hasil analisis sidik ragam (ANOVA) pada atribut hasil uji fisik diperoleh hasil bahwa perbandingan pemakaian tepung kacang koro pedang dan tepung maizena berbeda nyata $(\mathrm{p}<0,05)$ pada tingkat respon panelis terhadap kerenyahan cookies. Data hasil analisis uji fisik dapat dilihat padat Tabel 3.

Tabel 3.Nilai rata-rata kerenyahan crispy cookies kacang koro pedang

\begin{tabular}{cc}
\hline Perlakuan & $\begin{array}{c}\text { Rata-RataNilai Tekstur } \\
\text { gf (gram force) }\end{array}$ \\
\hline A0 & $479,90^{\mathrm{c}}$ \\
A1 & $426,37^{\mathrm{b}}$ \\
A2 & $410,90^{\mathrm{b}}$ \\
A3 & $365,17^{\mathrm{a}}$ \\
A4 & $362,80^{\mathrm{a}}$ \\
A5 & $363,63^{\mathrm{a}}$ \\
\hline
\end{tabular}

Keterangan :Notasi huruf yang berbeda pada tabel menunjukkan berbeda nyata pada tingkat kepercayaan 95\% $(\alpha=0.05)$ pada uji DUNCAN. 


\section{Analisis Kimia Formula Terpilih}

Formula terpilih (A4) berdasarkan hasil uji QDA selanjutnya dianalisis kimia mencakup kadar air, kadar abu, kadar protein, kadar serat kasar, kadar lemak, karbohidrat, dan HCN. Hasil analisis kimia crispy cookies dapat dilihat pada Tabel 4 . adalah maksimal 1,5\%. Dengan melihat data terpilih hasil penelitian, perlakuan A4 belum memenuhi syarat SNI.

\section{Kadar Lemak Total}

Lemak merupakan salah satu zat gizi yang penting untuk tubuh manusia, karena lemak merupakan salah satu sumber kalori yang

Tabel 4. Hasil analisis kimia crispy cookies berbahan baku tepung kacang koro pedang termodifikasi formulasi terpilih

\begin{tabular}{clcc}
\hline \multirow{2}{*}{ No } & \multicolumn{1}{c}{ Analisis } & Hasil & Standar SNI Biskuit No. 01- \\
& \multicolumn{2}{c}{ 2973-1992 } \\
\hline 1 & Kadar air (\%) & 1,34 & Maksimun 5 \\
2 & Kadar abu (\%) & 2,14 & Maksimun 1,5 \\
3 & Kadar serat kasar (\%) & 0,30 & Maksimun 0,5 \\
4 & Kadar lemak total (\%) & 30,30 & Minimun 9,5 \\
5 & Kadar protein (\%) & 14,33 & Minimun 9 \\
6 & Karbohidrat (\%) & 51,89 & Minimun 70 \\
7 & Kadar HCN (\%) & 0,01 & Maksimal 0,04\%* \\
\hline
\end{tabular}

Keterangan:

* SNI tepung singkong 01-2997-1996

\section{Kadar Air}

Kadar air merupakan banyaknya air yang terkandung dalam bahan. Kadar air merupakan salah satu karakteristik penting dalam pangan, karena air dapat mempengaruhi kenampakan, tekstur, dan rasa bahan pangan. Kadar air dalam crispy cookies sangat berpengaruh terhadap kerenyahan, daya tahan dan masa simpan crispy cookies. Kandungan air yang dihasilkan dari produk terpilih dalam penelitian ini adalah 1,34\%. Nilai kadar air yang disyaratkan dalam SNI adalah maksimal 5\%. Dengan melihat data terpilih hasil penelitian, perlakuan A4 memenuhi syarat SNI.

\section{Kadar Abu}

Kadar abu adalah zat anorganik sisa hasil pembakaran suatu bahan organik. Kadar air berhubungan dengan mineral suatu bahan. Penentuan kadar abu dilakukan dengan cara mengoksidasi bahan pada suhu tinggi. Kadar abu yang dihasilkan dari produk terpilih dalam penelitian ini adalah 2,14\% Nilai kadar abu yang disyaratkan dalam SNI diperlukan oleh manusia. Kadar lemak yang dihitung dalam produk ini adalah kadar lemak total dengan hasilnya yaitu 30,30\%. Nilai ini sesuai dengan persyaratan SNI biskuit yaitu kadar lemak minimun 9,5\%. Kadar lemak crispy cookies ini cukup tinggi dikarenakan bahan baku yang digunakan terutama lemak (margarin) cukup banyak.

\section{Kadar Protein}

Kadar protein hasil analisis formulasi terpilih adalah 14,33\%. Nilai ini sesuai dengan persyaratan SNI biskuit yaitu kadar protein minimun sebesar 9\%. Kadar protein ini merupakan target dalam pembuatan cookies berbahan baku kacang koro pedang, dimana kacang koro pedang yang memiliki kadar protein yang cukup tinggi dapat digunakan sebagai bahan baku pembuatan cookies dengan kandungan protein tinggi.

\section{Kadar Karbohidrat}

Kadar karbohidrat hasil analisis formulasi terpilih adalah 51,89\%. Nilai ini belum memenuhi standar SNI yaitu minimun 
70\%. Kadar karbohidrat bisa ditambahkan dengan penambahan bahan baku yang mengandung karbohidrat cukup tinggi.

\section{Kadar HCN}

Kadar HCN hasil analisis formulasi terpilih adalah 0,01\%. Nilai hasil analisis HCN ini mengacu pada SNI 01-2997-1996 dengan standar maksimal 0,04\% dari data hasil analisis formulasi terpilih memenuhi persyaratan.

\section{KESIMPULAN}

Produk terpilih dari formulasi pembuatan crispy cookies yaitu formula A4 dengan pemakaian $60 \%$ tepung kacang koro pedang termodifikasi dan $40 \%$ tepung maizena dan bahan-bahan lainnya. Faktor perbandingan penggunaan tepung kacang koro pedang dan tepung maizena berpengaruh terhadap respon panelis pada parameter aroma (langu, milky, buttery), rasa (pahit dan milky), tekstur, after taste (asam, pahit, langu) tetapi tidak berpengaruh terhadap rasa manis, asin, asam dan kenampakan crispy cookies. Produk terpilih memiliki kandungan kadar air 1,34\%, kadar abu total 2,14\%, kadar serat 0,30\%, kadar lemak $30,30 \%$, kadar protein 14,33\%, kadar karbohidrat 51,89\% dan kadar HCN 0,01\%. Berdasarkan analisis kimia tersebut menunjukan bahwa secara kimia produk crispy cookies berbahan baku kacang koro pedang masuk dalam standar SNI No. 012973-1992 pada semua parameter kecuali kadar abu dan kadar karbohidrat. Secara organoleptik produk yang dihasilkan masih memiliki karakteristik yang tidak diinginkan oleh panelis seperti aroma langu, after taste asam, pahit dan langu.

\section{SARAN}

Perlu dilakukan penelitian lebih lanjut untuk mengatasi aroma, rasa dan after taste yang tidak diinginkan pada crispy cookies berbahan baku tepung kacang koro pedang dengan penambahan bahan tambahan pangan seperti flavor atau bahan penunjang lain. Perlu dilakukan penelitian pembuatan crispy cookies berbahan baku tepung kacang koro pedang dengan penambahan tepung lain.

\section{DAFTAR PUSTAKA}

Adolina, P. 2007. Data komposisi margarin, Medan.

Ariyantoro, A.R., Rachmawati, D., dan Ikarini, I. 2016. Karakteristik fisikokimia tepung koro pedang (Canavalia ensiformis) termodifikasi dengan variasi konsentrasi asam laktat dan lama perendaman. Jurnal Agritech. 36(1):1-5.

[BSN]Badan Standarisasi Nasional. 1992. SNI 01-2891-1992 tentang cara uji makanan dan minuman. Standar Nasioanal Indonesia, Jakarta.

[BSN] Badan Standarisasi Nasional. 1997. SNI 01-2997-1996 tentang tepung singkong. Standar Nasioanal Indonesia, Jakarta.

[BSN] Badan Standarisasi Nasional. 2011. SNI 2973:201 tentang Biskuit. Standar Nasioanal Indonesia, Jakarta.

Buckle, K.A., Edwards, R.A., Fleet, G.H., and Wootton, M.2009. Ilmu Pangan. Hari Purnomo dan Adiono (Penerjemah). Penerbit Universitas Indonesia (UI Press), Jakarta. Terjemahan dari: Food Science.

Chusna, A.C.2017.Pengaruh penambahan jenis dan konsentrasi runput laut terhadap karakteristik mutu crispy cookies kaya serat [skripsi]. Fakultas Teknologi Industri Pertanian, Universitas Sahid Jakarta, Jakarta.

E-Publikasi. 2015. Statistik Konsumsi Pangan [internet]. Tersedia pada: http//epublikasi.setjen.pertanian.go.id/e publikasi/statistikpertanian/2015/STATI STIK\%20KONSUMSI\%PANGAN\%202015 /files/assets/basic-html/page126.html [19 Oktober 2017]. 
Kartika. 1987. Pedoman uji inderawi bahan pangan. Universitas Gadjah Mada, Yogyakarta.

Kasno, A. 2016. Koro Pedang (Canavalia Sp.) Komoditas Multiguna yang Terlupakan. Balai Penelitian Tanaman Aneka Kacang dan Umbi. Balitkabi, Bogor.

Kurniawati, 2012. Pengaruh subtitusi tepung terigu dengan tepung ubi jalar kuning terhadap kadar protein, kadar B-Karoten, dan mutu organoleptik roti manis [internet]. Journal of Nutrition College, Vol 1, Tersedia pada: http://EjournalS1.Undip.Ac.Id/index.Php Lnc [05 Maret 2018].

Masitoh, S. 2006. Pengaruh suhu pengeringan dan pemanasan awal (blancing) terhadap mutu tepung kacang koro (Dolichos lablab). Teknologi Pangan Universitas Teknik Universitas Pasundan, Bandung.

Rosenthal, A.J. 1999. Food Texture Measurement and Perception.An Aspen Publication Gaithersburg, Maryland.

Soliha, I. 2008. Aplikasi penggunaan tepung daging sapi sebagai bahan subtitusi sebagian tepung terigu dalam pembuatan cookie, .[skripsi]. Program Studi Teknologi Hasil Ternak, Fakultas Peternakan, Institut Pertanian Bogor, Bogor.

Suarni. 2000. Studi pembuatan kue kering (cookies) dari tepung sorgum sebagai bahan alternatif subtitusi terigu. Di dalam Prosiding Seminar Nasional Pengembangan Wilayah Lahan Kering, Universitas Lampung.

Utomo, L., Nurali, E., dan Ludong, M. 2015. Pengaruh penambahan maizena pada pembuatan biskuit gluten free casein free berbahan baku tepung pisang goroho (Musa acuminate). Jurnal Universitas Sam Ratulangi, Manado 8(1): 9-10.

Van Der Mesen dan Somaatmadja. 1993. Proses Sumber Daya Nabati Asia Tenggara I. Gramedia Pustaka Utama, Jakarta.
Wardiyono. 2008. Detail Data Cassia Fistula [internet]. http//www.kehati.com[23 September2016].

Winarno, FG. 1991. Kimia Pangan dan Gizi. PT. Gramedia Pustaka Umum, Jakarta. 